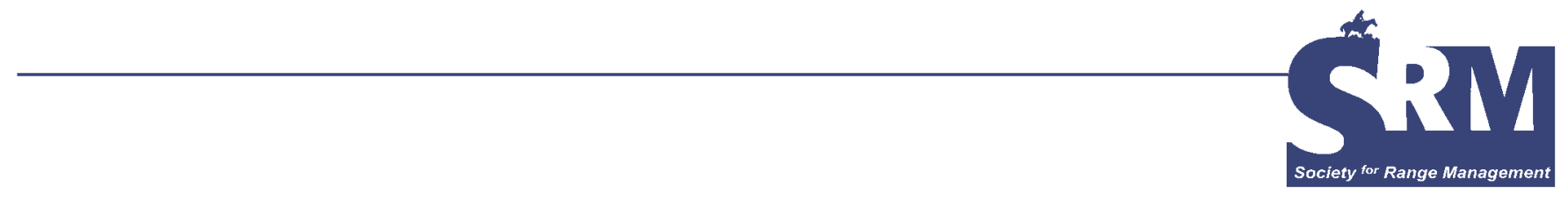

\title{
How a Student Views the Field
}

\section{By Jesse Dillon}

Editor's Note: This paper was presented at the Colorado Section, Society for Range Management, Annual Winter Meeting, Fort Collins, Colorado, December 9, 2005.

I t was the Colorado Section meeting in 2004 when the presiding president Rob Alexander told the members that one of his goals during his term was to tie bonds between the student chapter and the section. He said this was because "everything is more exciting for us when the students are involved." As the acting president of the Range Ecology Club at Colorado State University, thus the head of the student chapter at the time, I thought to myself, "How can I help to develop and encourage this bond?" Then it hit me. I should speak to the members at the next section meeting. During the next break, I found Rob Alexander, who was chatting with Roy Roath, the next president, and other members of the group, and introduced myself and suggested (perhaps foolishly) that I could speak at the next meeting if they thought it would be interesting.

About 6 months later, Roy Roath, who was in charge of organizing the meeting for 2005, approached me to say that he had developed the speakers list for the meeting and was counting on me to speak. I thought to myself, "Surely he is not holding me to an off comment I made nearly 6 months ago," but he was. So that is how it came that I would be speaking at the Colorado Section's 2005 meeting.

Approximately 1 week before the meeting I was starting to worry, I had spent considerable time thinking about my speech and still had no direction. The theme of the meeting was "Past, Present, and Future" and I was there to represent the future. My speech was titled "Preparing for a Career: How a College Student Views the Field" in the program for the meeting which had been distributed a month earlier. It was too late to back out now. I needed to focus and develop something to talk about. Again, I was hit with a moment of clarity, "Jesse," I said to myself, "you have heard all of your professors say 'you don't know where you are going, unless you know where you have been." I decided that I would tell my story of how I got into the field.

I grew up in a quaint little town of nearly 200,000 about 25 miles straight west of America's third largest metropolis, Chicago. Illinois is a state with a diminishing $0.01 \%$ of the historic rangelands, the tall-grass prairie. However, I was drawn to them in high school when I had taken a class entitled "Integrated Natural Resource Management (INRM)." This class taught basic ecological principles and processes but most importantly to me at the time it included many field trips with opportunities to leave school. On one of our field trips, we were taken to Treehaven, a field campus for natural resource students for University of Wisconsin-Stevens Point. On this trip I was exposed to multiple ecosystems and ecological processes. This exposure fueled my ever-growing interest in natural resources; so much so, that after this trip that I had decided that I would study natural resources in college.

The rest of that year in high school was spent looking at colleges and spending free time in the tall-grass prairie near my house. The prairie was located at Fermilab National Laboratory, an underground particle accelerator. They had a very intensive management plan and had even returned the native grazer of buffalo to their land. This land had truly drawn my interest. I really wanted to know how and why it worked as it did. At the same time the land was drawing my curiosity, my teacher from INRM class had suggested Colorado State 
University (CSU) as a place to continue my studies in natural resources.

Under that advisement of my teacher from the INRM class, I came to CSU in the fall of 2001 to study as a natural resource management major. I was told if I took a broad selection of classes I would be guaranteed to get a job in the field, a continued trend at CSU, which, in my estimation, is a common misconception. However, being young and naïve, I blindly followed this advice and took a wide range of classes to get me started within the major. It was not until I took my freshmen seminar course for natural resource majors that I was able to leave behind the idea of broad-based curriculum, and find the passionate focus of my education.

During this freshmen seminar course, one of the assignments in the class was to describe our dream job. As I was contemplating the question, I thought back to my fond memories in high school and the tall-grass prairies of Illinois. I had a very romantic view of natural resource management. I wrote "I want to restore tall-grass prairies and buffalo to the Midwest." Upon reading this response, the teacher's assistant for the class suggested I change majors to rangeland ecosystem science. That is exactly what I did; after all I was now on my way to save the world.

At the same time that I was learning I was in the wrong major, I was interested in getting involved in something related to natural resources on campus. I began to ask professors how I could find what I was looking for. I learned that CSU had received some sort of grant to get students interested in range management and with my new major; it was the perfect thing for me. I interviewed and was selected for placement in the Restoration Ecology Laboratory.

Things were finally going great for me; I had the right major for my dream job and was getting my first true experience in the Restoration Ecology Lab. However, I did have one problem: I had no idea what the heck range management was!!! This is another place where I think we might be failing at recruiting new range professionals. I think that we are not educating students early enough in their career about what range management is and what kind of jobs they can obtain with such a degree.

After working my first 2 semesters at CSU in the Restoration Ecology Lab, I realized this was a job I enjoyed and that I was learning stuff I found very interesting. I made the decision to join the field crew after a gracious offer from the professor in charge of the lab. This was another important opportunity that taught me so much about myself and the discipline of rangeland management. I loved being out in the field; the challenge of learning the plants and why they might be found in that particular area intrigued me. I liked my choice of study more and more each day.

To aid in my education of what rangeland ecosystem science was, I was directed to the Range Ecology Club on campus. The club offered me an opportunity for continued involvement and education of different aspects of rangeland management, beyond what I had learned in the Restoration
Ecology Lab. The club also offered me another opportunity. During my sophomore year at CSU, I was able to join the club on my first trip to an SRM International Conference.

I was on the road to Casper, Wyoming, for my first professional conference. I did not know what to expect, or why I was going as a sophomore, as most students from CSU go as upperclassmen. Already feeling out of place, when I arrived at the meeting I was able to understand that the society was actually a community. I was very different from a lot of the people at the meeting, however, I felt that I shared common interests and even identified with a lot of people at the meeting. I should note, by this time in my career, I had gotten over my romantic view of range management. After all, I am a scientist at heart. I felt that these people were my colleagues and would be a resource for me to draw continued knowledge from. Most of all, I felt like I belonged.

An epiphany occurred on my trip to Casper; I had the opportunity to see Bob Budd speak. As most everyone knows, Bob Budd has an amazing ability to move people and excite them about probably anything he is speaking about. In my case, he was speaking about cooperative management, and it was a packed house. I cannot remember exactly what he was saying, but I do remember that he made an analogy to working together like the three legs of a stool. His analogy had a personal impact on me when I applied it to my life. My education, field experience, and involvement in the Society were the three legs of my stool that supported me as a student and a young range professional. At this moment in time, I was never more confident that I had made the right decision by pursuing a career in range management. I was truly moved by his speech.

I now felt like I was on the right track as I continued to make decisions that I felt would make me a more attractive hire for a potential permanent job in the future. I continued my involvement in the Range Ecology Club and participated in numerous field trips and in-class learning opportunities. I became the president of the club my senior year and hopefully provided the leadership for upcoming range students to choose a path right for them, like previous presidents had done for me. I continued attending SRM International Conferences where I was awestruck by different people I had met and things that I was learning.

I was diversifying myself through different field experience by obtaining different summer positions. I spent 2 summers working in academia with the Restoration Ecology Lab field crew. Then, I moved on to take a job at a federal agency. My final summer in school, I decided take a job in the private sector. Each of these jobs taught me a different view of rangeland management. Receiving a proper amount of field experience is another place that I feel needs attention within higher education. With a lot of schools constrained by decreasing budgets, students are feeling increasing pressure to gain an appropriate amount of field experience for themselves in order to prepare for the impending job. Often, I think that the clubs are doing a good job providing some 
of those opportunities, but it is still up to students to supplement that experience themselves.

Similar to the range programs, the clubs also require continued support from their respective sections and the Society. Monetary and philosophical support will aid students in the clubs in reaching their ultimate goals within the field. Each and every member of the society can contribute by providing a few dollars by buying $\mathrm{T}$-shirts at our booths or by being a mentor to a student, providing guidance and support.

The people who are currently in the field have paved a path in range management. They have spent their lives fur- thering the science and understanding of rangelands. They have left the next generation with big shoes to fill. However, there are many students that have the passion to fill these shoes. We will continue to strive to better ourselves and continue the legacy of rangelands.

Author is a graduating student, Colorado State University, Fort Collins, CO 80523, jhdillon@gmail.com. 